Al-Huquq: Journal of Indonesian Islamic Economic Law, 2 (2), 2020: 160-174

ISSN: 2715-0003; E-ISSN 2714-5514

DOI: http://dx.doi.org/10.19105/al\%20huquq.v li1.3441

\title{
Perbandingan Penyelesaian Sengketa Ekonomi Syariah Pada Masa Nabi Muhammad SAW. dan di Era Reformasi
}

\author{
Nurul Umam, Erie Hariyanto \\ (Pasca Sarjana IAIN Madura Jl. Raya Panglegur Km. 4 Pamekasan 69371)
}

\begin{abstract}
Abstrak:
Pengadilan Agama memiliki kewenangan absolut menyelesaikan perkara di tingkat pertama antara orang yang beragama Islam di bidang perkawinan, waris, wasiat, dan hibah yang dilakukan berdasarkan hukum Islam, wakaf, shadaqah dan ekonomi syariah. Allah memerintahkan terhadap hambanya untuk memutuskan suatu hukum atau menghukumi manusia seperti apa yang diturunkannya. Rasulullah SAW. langsung mengadili dan menghukumi semua perkara yang muncul di tengah-tengah masyarakat dengan hukum yang diturunkan oleh Allah SWT. yang berkenaan dengan harta benda. Ketika terjadi persengketaan ekonomi syari'ah, maka diperlukan instrument penting sebagai sebuah solusi yang adil bagi para pihak-pihak yang bersengketa, dengan menggunakan model perdamaian, arbitrase, dan kekuasaan kehakiman. Penyelesaian sengketa yang di aplikasikan saat ini tidak berbeda jauh dari masa Nabi, perbedaannya hanya terletak pada sistem dan perkembangan zaman yang semakin modern, yaitu semuanya penyelesaian sengketa baik itu sengketa ekonomi, keluarga, maupun sosial sudah tertuang dalam peraturan-peraturan yang telah dikodifikasi dalam kitab undang-undang, hanya saja pengadilan atau tahkim saat ini menyampaikan dari catatan kecil tersebut. (Religious Courts have absolute authority to resolve first-level cases between Muslims in the fields of marriage, inheritance, wills, and gifts based on Islamic law, waqf, shadaqah and Islamic economic. Allah orders His servants to decide a law or punish humans as He sent them. Rasulullah SAW. directly judge and punish all cases that arise in the midst of society with the laws sent by Allah SWT. property related. When there is an economic dispute of Islamic law, an important instrument is needed as a fair solution for the disputing parties, using the model of peace, arbitration and the judiciary. The dispute resolution that is currently applied is not very different from the time of the
\end{abstract}

email koresproden: umamzeventz@gmail.com

https://creativecommons.org/licenses/by-nc/4.0/

Copyright (c) 2019 by al-huquq. All Right Reserved 
Perbandingan Penyelesaian Sengketa Ekonomi Syariah Pada Masa Nabi Muhammad SAW. dan di Era Modern

Prophet, the only difference lies in the increasingly modern system and the development of the time, that is, all dispute resolution, whether economic, family disputes or social, has been contained in the rules codified in the book. the law, it is just that the current court or tahkim is delivered from these little notes.)

Kata Kunci:

Penyelesaian, Sengketa, Ekonomi syariah

\section{Pendahuluan}

Kehancuran dan berkembangnya suatu beradaban tergantung komitmen manusianya sendiri karena yang menjadi pilar utama manusia ialah dalam bidang hukum. ${ }^{1}$ Noel J. Coulsum berpendapat dinamika hukum Islam menunjukkan sifat tarik ulur dan beperinsif konstan dan perubahan. ${ }^{2}$ Maka dengan demikian sangat sesuai dengan visi hukum islam, bahwa hukum islam harus mengikuti alur perubahan zaman dan keadaan sosial

Seiring dengan berkembangnya teknologi dan informasi pada era roformasi 4.0 , berdampak pula terhadap meningkatnya perkara di bidang ekonomi syariah. Dengan demikian aparat penegak hukum akan dituntut lebih untuk memiliki wawasan yang cukup komprehensif terkait permasalahan tersebut. Madsudnya berkas perkara yang timbul karena ekonomi syariah menjadi salah satu kompetensi absolut peradilan agama tentunya menjadi tantangan baru bagi penegak hukum di lembaga, yang mana pengadilan agama belum memiliki pengalaman hukum dalam menyelesaikan perkara ekonomi syariah tersebut. Fakta ini cukup beralasan mengingat luas dan beragamnya jenis-jenis transaksi ekonomi syariah yang terjadi pada masa saat sekarang ini.

Dengan demikian lembaga peradilan Agama harsus lebih menyiapkan para hakim agar dalam meberika putusan yang berkenaan dengan ekonomi syariah tetap dapat memeriksa dan mengadili segala dan bentuk sengketa yang diajukan oleh para yang

\footnotetext{
${ }^{1}$ Muhammad Abi Al-Jabiri,.Taqwin al-aql al'rab (Bairud: Markas alwahdah al-arabiyah .1989) hlm. 96.

2 Noul J. Coulsum,. Comflic and tersion in islamic Yurisprudence (Chicago and London: The Uneversiy of Chicago and London press,.tth,), hlm. 50.
} 
melakukan pengajuan persengketaan. Perluasan kewenangan Pengadilan Agama (PA) disesuaikan dengan perkembangan hukum dan kebutuhan masyarakat perluasan tersebut meliputi bidang ekonomi syariah, undang-undang mnyatakan pada Nomor 7 Tahun 1992 tentang perbangkan sebagaimana hal ini telah diubah dengan undang-undang nomor 10 tahun 1998 hal ini mengatur tentang biayaan berdasarkan perinsip syariah. Prinsip syariah dimaksud aturan perjanjian yang berdasarkan hukum Islam baik antara pihak bank dan pihak penyimpanan dana dan pembiyaan kegiatan usaha kegiatan lain mudharabah, musyarakah dan murabahah. ${ }^{3}$

Dalam undang-undang nomor 48 tahun 2009 yang diakui eksitensinya ialah Peradilan Agama didalam kekuasaan kehakimana, yang merupakan lembaga yang memiliki wewenang untuk memeriksa, mengadili, memetus dan menyelesaikan perkara-perkara tertentu antara orang yang beraga Islam. Adapun kewenangan absolut Pengadilan Agama dijelaskan dalam undang-undang4 yaitu pengadilan agama bertugas menyelesaikan perkara di tingkat pertama antara orang yang beragama Islam di bidang Perkawinan, waris, wasiat, dan hibah yang dilakukan berdasarkan hukum Islam, Wakaf dan shadaqah.

Penerapan prinsip-prinsip syariah dalam bidang perekonomian pada gilirannya menuntut perubahan dalam berbagai bidang yang berkaitan, termasuk berkenaan dengan peraturan perundang-undangan. Lebih dari itu, penerapan sistem perbankan syariah juga berimplikasi terhadap peraturan perundang-undangan terkait institusi lain, salah satunya adalah lembaga peradilan.

\section{Penyelesaian Sengketa Ekonomi Syariah pada Masa Nabi dan Sahabat}

Penyelesaian sengketa ekonomi syariah dapat kita lihat dari kejadian sehari-hari pada masyarakat arab pada masa kemimpinan Rosulullah SAW. Pelajaran ini di ambil dari kasus-kasus yang terjadi dan dapat di ikuti hingga saat ini, ada tiga model penyelesaian sengketa yang dapat kita jadikan acuan yaitu: Pertama Penyelesaian

\footnotetext{
${ }^{3}$ Eri Hariyanto, "Penyelesaian Sengketa EkonomiSyariah", Jurnal Iqtishadia Vol. 1 No. 1 Juni 2014, hlm. 43.

4 Pasal 49 UU Nomor 7 Tahun 1989 tentang Kekuasaan Kehakiman.
} 
Perbandingan Penyelesaian Sengketa Ekonomi Syariah Pada Masa Nabi Muhammad SAW. dan di Era Modern

dengan cara al-Shulh (Perdamaian). Kedua melalui Tahkim (arbitrase), dan ketiga melalui wilayat al-qadha (kekuasaan kehakiman).

Dalam menyelesaikan sebuah sengketa islam sangat menganjurkan yang pertama dengan cara al-Shulh atau perdamaian antar pihak-pihak yang mempunyai kesengketaan, dalam firmannya menyatakan sangat mencintai dan menyayangi kedamaian, maka dengan usaha untuk menyelesaikan sengketa dengan melakukan perdamaian, perdamaian merupakan sebuah tuntutan yang di ajarkan oleh Islam, dengan demikian sanat selaran dengan Firman Allah Swt. Dalam al-qur'an Surat Al-hujurat Ayat 10.

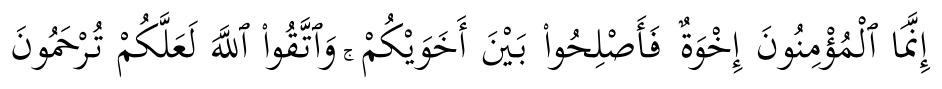

Artinya: sesungguhnya orang yang mukmin itu bersaudara, maka damaikanlah anatara kedua saudaramu (yang berselisish) dan bertakwalah kepada Allah agar kamu mendapatkan rahmat. ${ }^{5}$

Dalam sebuah bahasa al-Shulh diartikan memutuskan pertengkaran dan meredang pertikaian. Sedangkan dalam istilah $\mathrm{Al}$ Shulh di artikan suatu jenis akad atau suatu perjanjian untuk mengakhiri sebuah perselisihan (pertengkaran) antara dua belah pihak yang bersengketa secara damai. ${ }^{6}$ Perdamaian bisa dilakukan dengan proses apabila parak pihak yang bersengketa sepakat ingin melakukan perdamaian, kesepakatan antara pihak yang bersengketa berlangsung dengan dasar keihklasan, bukan karena dasar keterpaksaan, al-Shulh jugak mempunyai rukun dan syarat sah yang menjadi suatu keharusan yang harus terpenuhi agar proses dapat direalisasikan. Rukun dan Syarat dapat di lihat dalam beberapa aspek di antaranya:

1. Para pihak yang melakukan perdamaian (Mushalih)

Parak pihak yang melakukan perdamaian hendaknya cakap bertindak dan mempunyai kekuasaan untuk melepaskan haknya atau hal-hal yang bersangkut paud dengan perdamaian, karenanya orang yang cakap bertindak belum tentu mempunyai kekuasaan dan wewenang. Ada beberapa orang yang cakap dalam bertindak menurut hukum Islam, akan tetapi tidak

\footnotetext{
5 Tubagus Najib al-Bantani, Al-Qur'an Mushaf Al-Bantani (Bantani: MUI Provinsi Banten ,2012), hlm. 516.

${ }^{6}$ Kamus Al-Munawir , Pondok Pesantren Al-Munawir , Yogyakarta, 1984, hlm. 843.
} 
memiliki wewenang adalah Wali atas harta benda atau orang orang yang ada dibawah pewaliannya, Pengampu atas suatu harta benda yang ada di bawah pengampuannya dan Pengawas (nazir) wakaf atas hak milik wakaf yang ada dibawah pengawasannya.

2. Objek yang dipersengkatakan (Mushalih bih)

Persengketaan ekonomi pada dasarnya yang menjadi objek adalah yang menyangkut dengan harta benda setiap harta dikatakan benda ialah dengan emiliki unsur-unsur seperti berikut : pertama Bersifat terwujud dan berbentuk materil, kedua Sesutu yang bernilai tradisi yang dipandang oleh masyarakat sebagaia harta dan ketiga Sesutu yang bersifat halal, ketiga Bisa di ambil mamfaatnya 7

3. Persoalan yang dapat diselesaikan (Mushahihbih)

Yaitu yang menyangkut dengan bidang ekonomi harta benda antar sesame manusia dan dapat didamaikan. Ijab dan qabul (sigat) sebagai suatu Keberhasilan suatu persengketaan dapat dibuktikan dengan ijab dan qabul antara pihak yang terlibat dalam persengketaan, dan dalam proses perdamaian tidak boleh atas dasar keterpaksaan ataupun ada paksaan dari pihak manapun, atinya proses perdamaian ini benar-benar terjadi tanpa ada unsur-unsur rekayasa dari pihak-pihak yang melakukan persengketaan.

Dalam proses penyelesaian sengketa di atas dengan cara Shulh bisa dilakukan melalui media prantara atau menujuk wali yang di sepakati oleh pihak-pihak yang bersengketa, selanjutnya dilakukan musyawarah untuk membahas masalahmasalah dan mencarikan solusinya. Dengan begitu Shulh lebih menekankan kepada system kekeluargaan, dengan cara melalui jalan musyawarah dengan tujuan mencari kebenaran dan kesepakatan bersama, apabila proses sengketa melaui Shulh tidak menemukan titik temu, maka para pihak bersengketa

7 Ghufran A. Mas'adi, Figh muamalah Kontekstual (Jakarta: Raja Grafindo Persada, 2002), hlm. 12. 
Perbandingan Penyelesaian Sengketa Ekonomi Syariah Pada Masa Nabi Muhammad SAW. dan di Era Modern

melakukan tahapan pada berikutnya yaitu melalui Peradilan, dengan melakukan tersebut dengan maksud untuk mendapatkan kepastian hukum bagi para pihak yang bersengketa.

1. Tahkim (Arbitrase)

Cara selain cara di atas dapat kita tempuh dalam penyelesaian sengketa yang berkaitan dengan harta benda yang di ajarkan oleh Islam ialah Tahkim model penyelesaian sengketa seperti ini sudah lama diterapkan sejak zaman Rosulullah SAW. Yang dalam behasa Arab Tahkim yang berasal dari kata Hakkama yuhakkimu, takhiman, yang di artikan menjadikan seseorang untuk menjadi penegak dalam sebuah sengketa. ${ }^{8}$

Sedangkan dalam terminologis, Tahkim diartikan pengangkatan seseorang atau sebagai juru damai oleh dua orang bagi orang yang melakukan sengketa, dengan madsud untuk menyelesaikan sengketa yang mereka sengketakan. ${ }^{9}$ Dalam arti lain Tahkim adalah untuk mendapatkan perlindungan antara dua belah pihak yang bersengketa kepada orang yang mereka sepakati dan setuju (sebagai penengah) serta menerima keputusannya dalam menyelesaikan persengketaan di antara mereka, dengan demikian sebagai seorang juru damai dilakukan secara suka rela atau tampa ada paksaan dari kedua belah pihak yang sedang melakukan persengketaan. ${ }^{10}$

Yang menjadikan dasar dalam menyelesaian sengketa dengan metode Tahkim terdapat dalam Al-Qur'an surat Annisa' ayat 35:

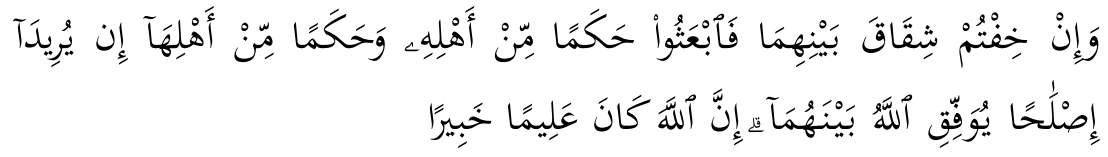

Artinya: Dan jika kamu khawatirkan ada persengketaan antara keduanya, Maka kirimlah seorang hakam dari keluarga laki-laki dan seorang hakam dari keluarga perempuan. jika kedua orang hakam itu

\footnotetext{
8 Satria Efendi M. Zein, Arbitrase Dalam Syariah Islam, dalam Arbitrase Islam di Indonesia, Badan Arbitrase Muamalat Indonesia (Jakarta: BAMUI,1994), hlm. 7.

${ }^{9}$ M. Zein, Arbitrase dalam syariah Islam, hlm. 31.

10 Enksiklopediam Hukum Islam,. Jilid V Jakarta: PT Ictiar Baru Van Hoove,.1997, hlm. 157.
} 
bermaksud Mengadakan perbaikan, niscaya Allah memberi taufik kepada suami-isteri itu. Sesungguhnya Allah Maha mengetahui lagi Maha Mengenal.

Ayat di atas memperjelas bahwa jika terjadi persengketaan di antara dua belah pihak atau lebih, hendaknya ada orang yang menjadi penengah untuk menyelesaikan persengketaannya, orang menyelesaikan persengketaan di kenal dengan sebutan hakam. Seorang hakam hendaknya memiliki kemampuan berdiplomasi untuk menyelesaikan persengketaan sehingga para pihak dapat menerimanya.

2. Kekuasaan kehakiman (wilayat al-Qadha)

Dalam hukum Islam terdapat tiga model kekuasaan yang disebut sebagai penegak hukum, pertama, al-qhada (lembaga peradilan) yang memiliki kekuasaan dalam menyelesaikan masalah-masalah perdata, pidana, dan hukum keluarga. Kedua al-hisbah merupakan lembaga resmi Negara yang diberikan wewenang untuk menyelesaikan perkara-perkara yang ringan dan tidak perlu diselesaikan dilembaga peradilan, seperti halnya dalam kecurangan takaran, pemalsuan dan penipuan. Ketiga, la-madzalim yang merupakan lembaga yang berkedudukan untuk membela hak-hak rakyat yang teraniaya akibat penyelewengan kekuasaan Negara, atau kebijakan Negara yang tidak memihak, seperti narapidana koruptor dan suap menyuap. ${ }^{11}$

Kata al-Qadha dalam istilah tradisi di artikan pada makna yang berkaitan dengan praktik dan putusan peradilan. Al-Qadha merupakan perkara yang di syariatkan oleh al-Qur;an dan Hadist. Allah SWT. Memerintahkan untuk memutuskan hukum atau menghukumi dengan apa yang sudah diperintahkan oleh Allah. ${ }^{12}$

Dengan demikian Rosulullah SAW. Mengadili dan menghukumi perkara yang muncul di tengah-tengah masyarakat dengan hukum Allah SWT. Selain itu Rosulullah juga memberikan putusan dalam beberapa masalah pernikahan, masalah harta, muamalah, dan uqubat umumnya; dan juga

\footnotetext{
11 Juhaya S. Praja, Ekonomi Syariah (Bandung: Pustaka Setia, 2008), hlm. 64. 12 Praja, Ekonomi Syariah,.
} 
Perbandingan Penyelesaian Sengketa Ekonomi Syariah Pada Masa Nabi Muhammad SAW. dan di Era Modern

seperti masalah hisbah seperti ketika beliau mendapati pedagang di pasar yang dicampuri gandung basah dan gandum kering, dan dalam masalah mazhalim mengenai penetapan harga; dan dalam perselisihan anatara zubair bin awwam dan seorang Anshar dalam masalah perairan dan sebagainya. ${ }^{13}$ Ketika kekuasaan Negara Islam semakin meluas, Rasulullah SAW mengangkat sahabat sebagai hakim yang beliau tempatkan di berbagai daerah, seperti halnya muadz bin jabal di daerah janad, Ali bin abi thalib di daerah yaman dan masih banyak hakim lainnya seperti; Umar bin Khattab, Ali bin Abi Thallib, Ibn Mas'ud, Ubay bin kaab, Zaid bin Tsabit, dan Abu Musa al-Asy'ari.

Rasulullah setiap akli mengutus sahabatnya keberbagai daerah selalu memberikan bimbingan dan pesan-pesan yang berkaitan dengan penyelesaian sengketa, para sahabat juga melakukan hal sama, yang terkenal adalah surah Khalifah Umar ibn Khattab kepada abu Musa al-Asy'ari yang isinya berkenaan dengan pokok-pokok penyelesaian sengketa di Peradilan. ${ }^{14}$ Yang menjadi alat bukti pada masa itu ialah saksi dan sumpah. Sedangkan hasil putusan setiap persengketaan pada masa itu belum dibukukan.

Pada masa Umayyah, Hakim-hakim yang berada di pusat pemerintahan diangkat oleh Khalifah, sedangkan yang berada di daerah-daerah diangkat oleh penguasa daerah dengan kewenangan dan perkara-perkara khusus hakim. Hakim yang ada pada saat ini juga dikatan seorang mujtahid dan bersifat sangat independen. ${ }^{15}$

Putusan hukum pada masa khulafa' al-rasyidin didasarkan pada al-Qur'an,Assunah,ijma' sahabat pada masa Umar bin khattab, mengingat semakin luasnya wilayah Islam dan menjadi keharusan untuk mememerhatikan urusan-urusan pemerintahan diberbagai daerah maka dimulailah pemisahan antara eksekutif dan yudikatif, dan hakim-hakim mulai di

${ }^{13}$ Dedi Supriyadi, Sejarah beradaban Islam (Bandung: Pustaka Setia, 2008), hlm. 64.

14 Surat 'Umar ibn Khattab kepada Gubenur Abu Musa al-Asy'ari yang dikenal dengan Arrisalah al-Qada.

${ }_{15}$ Hasbi Ash-Shiddieqy, Peradilan dan Hukum Acara Islam (Bandung: PT.Al-Ma'arif,tt.), hlm. 20 . 
angkat melalui kewenangan yang berdasarkan wilayah-wilayah dan materi perkara, seperti halnya abu darda (Madina) Syurayh (Basrah), Abu Musa al-asy'ari (kufah) dll. Untuk public dipegang oleh penguasa daerah sedang dengan urusan perdata dipegang oleh hakim-hakim yang di angkat oleh Khalifah. Pada masa utsman bin affan pengadilan tinggi mulai di adakan yang semulanya lembaga pengadilan dilakukan di masjid-masjid, pendelegasian dilakukan oleh khalifah Ali Bin Abi Thalib dengan mengutus al-Nakha'I ke Mesir untuk menjadi gubenur sekaligus sebagai hakim.

Penyelesaian Sengketa Ekonomi Syariah di Indonesia

Pengembangan Bank syariah merupakan suatu alternatif sistem pelayanan jasa bank yang menerapkan pola pembiayaan usaha dengan prinsip bagi hasil sebagai salah satu pokok dalam kegiatan perbankan Syariah sehingga sangat kecil kemungkinan terjadinya kegagalan usaha ${ }^{16}$. dengan kelebihan tersebut, menarik masyarakat baik muslim ataupun non muslim untuk menjadi nasabah pada lembaga perbankan syariah. Namun timbul Persoalan jika dikemudian hari terjadi perselisihan, apakah peradilan agama masih tetap berwenang untuk mengadili sengketa tersebut karena sebagaimana diketahui bahwa Peradilan agama merupakan peradilan khusus yang menyelesaikan sengketa perdata bagi pemeluk agama Islam. ${ }^{17}$ Dalam Pasal 2 UU No. 50 Tahun 2009 dijelaskan bahwa peradilan agama merupakan salah satu kekuasaan kehakiman bagi rakyat pencari keadilan yang beragama Islam mengenai perkara perdata tertentu.

16 Asas-asas Umum dalam Undang-Undang RI Nomor 7 Tahun 1989 tentang Peradilan agama yaitu: (1). Asas Personalitas KeIslaman, (2). Asas Kebebasan, (3). Asas Wajib Mendamaikan; (4). Asas persidangan terbuka untuk umum; (5). Asas legalitas; (6). Asas Cepat, sederhana dan biaya ringan; (7). Asas Equality; (8). Asas Aktif memberikan bantuan.

17 Pasal 10 Undang-Undang RI Nomor 4 Tahun 2004 tentang Kekuasaan Kehakiman bahwa kekuasaan kehakiman dilakukan oleh pengadilan dalam lingkungan peradilan umum dan peradilan khusus, yang terdiri dari lingkungan peradilan agama, militer serta tata usaha negara dan spesialisasi dalam masing-masing lingkungan peradilan. 
Penulis berpendapat dalam Pasal 2 Undang-Undang Peradilan Agama itu dikatakan Peradilan Agama melekat pada asas personalitas ke Islaman yang bermakna bahwa Pertama: pihak yang berperkara harus sama-sama memeluk agama Islam, Kedua: perkara yang disengketakan perkara dibidang perkawinan, waris, hibah, zakat, wakaf, dan ekonomi syariah, Ketiga: hubungan hukum yang melandasi keperdataan berdasarkan Islam dan diselesaikan pula berdasarkan hukum Islam. Dalam aturan tersebut dijelaskan bahwa Penerapan asas personalitas keIslaman didasarkan pada saat terjadinya hubungan hukum. Seseorang yang mengaku Islam, maka dirinya melekat asas personalitas keislaman.

Berbeda dengan apa yang dikemukakan oleh Abdul Gani Abdullah $^{18}$ bahwa asas personalitas ke Islaman lebih menekankan pada agama pihak pengaju perkara, tanpa mempedulikan agama pihak lawan. Jadi, apabila terjadi sengketa ekonomi syariah dengan nasabah non muslim, maka hukum yang berlaku dalam menentukan kompetensi peradilan bukanlah hukum yang melahirkan hubungan hukum, tetapi berdasarkan agama dari pihak pengaju perkara. Sehingga tidak menutup kemungkinan perkara ekonomi syariah diselesaikan pada Pengadilan Negeri, karena Penentuan kewenangan pengadilan tersebut berdasarkan Asas tigalistis yaitu: asas hukum terapan, asas hukum agama pengajuan perkara dan asas pilihan hukum.

Undang-Undang Peradilan Agama telah mengatur mengenai tugas dan kewenangan peradilan agama sehingga, penentuan kompetensi absolut PA seharusnya mengacu pada asas personalitas keislaman. Dengan demikian peradilan agama berkompetensi dalam menangani perkara ekonomi syariah walaupun pihak nasabah non muslim, karena seseorang yang beragama non muslim menjadi nasabah pada lembaga

\footnotetext{
18 Abdul Gani Abdullah, Pengantar Kompilasi Hukum Islam dalam Tata Hukum Indonesia (Jakarta: Gema Insani Press, 1994), hlm. 50-52.
} 
perbankan, tentunya akan melakukan hubungan hukum, sehingga melekatlah personalitas keIslaman karena dengan sendirinya menundukkan diri dan suka rela pada ketentuan ekonomi syari'ah, baik dalam hal pelaksanaan akadnya maupun dalam hal penyelesaian perselisihannya.

Dalam menyelesaikan persengketaan kehakiman diharuskan harus merujuk pada ketentuan UU No. 3 tahun 2006 atas pergantian atas UU No. 7 tahun 1989 tentang Peradilan Agama. Dan juga Peradilan Agama telah diatur pada pasal 49 sampai pasal 53 dan pasal 66 serta pasal 73, serta ketentuan tersebut diatur mengenai kewenangan kehakiman di lingkungan Kementrian Agmama.

Penegakan hukum pada prinsipnya hanya dilakukan oleh kekuasaan kehakiman (judicial Power) yang secara konstitusional lazim disebut badan yudikatif (Pasal 24 UUD 1945). Dengan demikian, maka yang berwenang memeriksa dan mengadili sengketa hanya badan peradilan yang bernaungan di bawah kekuasaan kehakiman yang berpuncak di Mahkamah Agung. ${ }^{19}$ Pasal 2 UU No. 14 Tahun 1970 secara tegas menyatakan bahwa yang berwenang dan berfungsi melaksanakan peradilan hanya badan-badan peradilan yang dibentuk berdasarkan undang-undang. Di luar itu tidak dibenarkan karena tidak memenuhi syarat formal dan official serta bertentangan dengan prinsip under the authority of law. Namun berdasarkan Pasal 1851,1855,1858 KUHP, Penjelasan Pasal 3 UU No. 14 Tahun 1970 serta UU No. 30 Tahun 1999 tentang Arbitrase dan Alternatif Penyelesaian Sengketa, maka terbuka kemungkinan para pihak menyelesaikan sengketa dengan menggunakan lembaga selain pengadilan (non litigasi), seperti arbitrase atau perdamaian (islah). ${ }^{20}$

19 Eri hariyanto, "Penyelesaian Sengketa Ekonomi Syariah di Indonesia", Jurnal Iqtishadia Vol.1. No.1 Juni 2014, hlm. 50.

${ }^{20}$ Karnaen Perwataatmaja, dkk., Bank dan Asuransi Islam di Indonesia (Jakarta: Prenada Media, 2005), hlm. 288. 
Perbandingan Penyelesaian Sengketa Ekonomi Syariah Pada Masa Nabi Muhammad SAW. dan di Era Modern

\section{Penyelesaian Sengketa Ekonomi Syariah Syariah Berdasarkan Peraturan Perundang-undangan}

Dengan munculnya PERMA No. 14 Tahun 2016 memang sangat dinanti-nantikan, terutama oleh para hakim di bawah lingkungan peradilan agama, dengan madsud sebagai pedoman dalam tata cara penyelesaian perkara ekonomi syari'ah. ${ }^{21} \mathrm{Hal}$ ini sangat membantu peran hakim dalam menyelesaikan perkara ekonomi syariah yang masuk. Di dalam PERMA tersebut dijelaskan berbagai macam peraturan proses penyelesaian sengketa ekonomi syariah.

Dimulai dari menjelaskan mengenai penjelasan singkat lingkup sengketa ekonomi syariah serta pengertian masingmasing point, kemudian tata cara pemeriksaan perkara dengan acara sederhana, dengan nominal yang diperkarakan maksimal Rp 200.000.000,- dengan alur pendaftaran gugatan hingga putusan dikeluarkan oleh hakim tunggal.

Pemeriksaan perkara sebagaimana dimaksud pada ayat (2) mengacu pada Peraturan Mahkamah Agung Nomor 2 Tahun 2015 tentang Tata Cara Penyelesaian Gugatan Sederhana kecuali hal-hal yang diatur secara khusus dalam Peraturan Mahkamah Agung ini.

Dengan kata lain, PERMA ini juga mengatur pelaksanaan putusan arbitrase syariah dan pembatalannya yang mempertegas kewenangan pengadilan agama sehingga sudah tidak terjadi lagi dualisme pelaksanaan putusan dan pembatalan arbitrase syariah antara pengadilan agama dan pengadilan negeri. Hal ini termuat dalam Pasal 13 ayat (2) PERMA Sengketa Ekonomi Syariah yang menyebutkan bahwa "pelaksanaan putusan arbitrase syariah dan pembatalannya, dilakukan oleh Pengadilan dalam lingkungan peradilan agama." Namun, tata cara pelaksanaan putusan putusan arbitrase syariah tetap mengacu pada UU No. 30 Tahun 1999 tentang Arbitrase dan Alternatif Penyelesaian Sengketa.

Tidak hanya begitu, PERMA juga mengatur tentang kewenangan Pengadilan Agama yang menangani urusan

\footnotetext{
${ }^{21}$ Mahkamah Agung, PERMA NO. 14 tahun 2016.
} 
eksekusi hak tanggungan dan fidusia yang menggunakan akad syariah. Hal ini ini dapat diperjelas dalam Pasal 13 ayat (1) PERMA Sengketa Ekonomi Syariah, yaitu "pelaksanaan putusan perkara ekonomi syariah, hak tanggungan dan fidusia yang berdasarkan akad syariah dilakukan oleh Pengadilan dalam lingkungan Peradilan Agama."

PERMA juga mengakomodir layanan teknologi informasi seperti pendaftaran gugatan dan pembuktian terutama dalam pemeriksaan ahli. Hal ini sesuai dengan Pasal 4 dan 11 PERMA Sengketa Ekonomi Syariah. Pasal 4 diatas menyebutkan bahwa "penggugat mengajukan gugatannya di kepaniteraan pengadilan atau melalui pendaftaran elektronik atau dapat mendaftarkan gugatannya dengan mengisi blanko yang disediakan di kepaniteraan." Dan Pasal 11 menyatakan bahwa "Pemeriksaan ahli dapat dilakukan dengan menggunakan bantuan teknologi informasi."

Lebih jauh, PERMA ini juga menverifikasi hakim yang dapat memeriksa dan mengadili sengketa ekonomi syariah, misalnya harus bersertifikasi hakim ekonomi syariah, atau seminimal mungkin hakim agama yang pernah mengikuti diklat fungsional ekonomi syariah.

Blanko gugatan berisi keterangan mengenai: 1). identitas penggugat dan tergugat; 2). penjelasan ringkas duduk perkara; 3 ). tuntutan penggugat; dan 4). wajib melampirkan bukti surat yang sudah dilegalisasi pada saat mendaftarkan gugatan sederhana.

Perbandingan yang penulis dapat simpulkan pada artikel ini ialah model penyelesaian sengketa pada masa Nabi dengan 3 model Pertama Penyelesaian dengan cara al-Shulh (Perdamaian). Kedua melalui Tahkim (arbitrase), dan ketiga melalui wilayat al-qadha (kekuasaan kehakiman). Sedangkan dalam penyelesaian sengketa pada masa saat ini tidak berbeda jauh dengan penyelesaian sengketa pada masa Nabi hanya saja dalam tarap pengaplikasiannya yang berbeda, ada penyelesaian sengketa dengan cara letigasi dan non litigasi, dan harus mengikuti prosedur yang berlaku saat ini. 
Perbandingan Penyelesaian Sengketa Ekonomi Syariah Pada Masa Nabi Muhammad SAW. dan di Era Modern

\section{Kesimpulan}

Penyelesaian sengketa sudah berjalan begitu lama sudah menjadi tradisi pada masa Rasulullah SAW. Kapasitas beliau juga mencakup sebagai hakim, penyelesaian sengketa di selesaikan dengan Pengadilan Agma yang dikenal dengan istilah sekarang litigasi dan melalui shulh, dan tahkim yang dikenal sekarang sengan nonlitigasi.

PERMA No. 14 Tahun 2016 memang sangat dinantinantikan, terutama oleh para hakim di bawah lingkungan peradilan agama, dengan madsud sebagai pedoman dalam tata cara penyelesaian perkara ekonomi syari'ah. Hal ini sangat membantu peran hakim dalam menyelesaikan perkara ekonomi syariah yang masuk. Di dalam PERMA tersebut dijelaskan berbagai macam peraturan proses penyelesaian sengketa ekonomi syariah.

\section{Daftar Pustaka}

Abdul Gani Abdullah, Pengantar Kompilasi Hukum Islam dalam Tata Hukum Indonesia, Jakarta: Gema Insani Press, 1994

Al-Bantani Tubagus Najib, Al-Qur'an Mushaf Al-Bantani, Bantani: MUI Provinsi Banten ,2012,.

Ash-Shiddieqy Hasbi, Peradilan dan Hukum Acara Islam, Bandung: PT.Al-Ma'arif, tt.

M. Zein Satria Efendi, Arbitrase Dalam Syariah Islam, dalam Arbitrase Islam di Indonesia, Badan Arbitrase Muamalat Indonesia, Jakarta: BAMUI, 1994.

Mas'adi Ghufran A., Fiqh muamalah Kontekstual, Jakarta: Raja Grafindo Persada, 2002.

Perwataatmaja, Karnaen dkk, Bank dan Asuransi Islam di Indonesia, Jakarta: Prenada Media, 2005. 
Praja Juhaya S., Ekonomi Syariah, Bandung: Pustaka Setia, 2008.

Supriyadi, Dedi, Sejarah beradaban Islam, Bandung: Pustaka Setia, 2008.

Eri Hariyanto, "Penyelesaian Sengketa Ekonomi Syariah di Indonesia", Jurnal Iqtishadia Vol.1. No.1 Juni 2014.

Surat ‘Umar ibn Khattab kepada Gubenur Abu Musa al-Asy’ari yang dikenal dengan Arrisalah al-Qada.

Enksiklopediam Hukum Islam,. Jilid V Jakarta: PT Ictiar Baru Van Hoove,.1997,.

Kamus Al-Munawir, Pondok Pesantren Al-Munawir, Yogyakarta, $1984, .843$.

Undang-Undang RI Nomor 4 Tahun 2004 tentang Kekuasaan Kehakiman

Undang-Undang RI Nomor 7 Tahun 1989 tentang Peradilan agama

Peraturan Mahkamah Agung (PERMA) Nomor 14 tahun 2016. 